\title{
PERBEDAAN TINGKAT STRES MAHASISWA PRAKTIK KLINIK PADA TINGKAT II DAN III PROGRAM STUDI D-III KEPERAWATAN STIKes KEPANJEN
}

\author{
Qori Fanani \\ Sekolah Tinggi Ilmu Kesehatan Kepanjen \\ gori.fanani1084@gmail.com
}

\begin{abstract}
Nursing students often experience stress or stress in undergoing clinical practice. There are several factors that cause students to experience stress, including lack of knowledge and skills, workloads and assignments, and the clinical environment itself. The purpose of this study was to determine the differences in stress levels of clinical practice students at level II and level III of Nursing Diploma III Program at STIKes Kepanjen. This type of research is descriptive quantitative with a causal comparative approach with a total of 60 respondents. The research instrument used the adopted from Perceived Stress Scale (PSS) with 29 statement. Data analysis using Mann - Whitney so that the results show that there are significant differences in the level of stress level II and level III students in conducting clinical studies. While for the stressors of students who are undergoing clinical practice are lack of knowledge and skills, workload and assignments, hospital environment and when caring for patients. So that to achieve the goal of clinical learning is to prepare students both knowledge, skills and maturity in dealing with pressure when carrying out clinical learning.
\end{abstract}

\section{Keywords : Clinical practice, Nursing Student}

Abstrak : Mahasiswa keperawatan sering kali mengalami tekanan atau stres dalam menjalani praktik klinik. Terdapat beberapa faktor yang menjadi penyebab mahasiswa mengalami stres antara lain kurangnya pengetahuan dan keterampilan, beban kerja dan tugas serta lingkungan klinik itu sendiri. Tujuan dari penelitian ini adalah untuk mengetahui perbedaan tingkat stres mahasiswa praktik klinik pada tingkat II dan tingkat III Program Diploma III Keperawatan STIKes Kepanjen. Jenis penelitian ini adalah deskripstif kuantitatif dengan pendekatan causal comparative dengan total responden 60 responden.Instrumen dalam penelitian ini menggunakan kuesioner yang diadopsi dari Perceived Stress Scale (PPS) yang terdiri dari 29 pernyataan. Analisa data menggunakan Mann-Whitney sehingga diperoleh hasil bahwa terdapat perbedaan yang bermakna tingkat stres mahasiswa tingkat II dan tingkat III dalam melakukan studi klinik. Sedangkan untuk penyebab stres mahasiswa yang sedang menjalani praktik klinik adalah kurangnya pengetahuan dan keterampilan, beban kerja dan tugas, lingkungan rumah sakit dan pada saat merawat pasien. Sehingga untuk mencapai tujuan dari pembelajaran klinik adalah menyiapkan mahasiswa baik secara pengetahuan, keterampilan dan kematangan dalam mengahadapi tekanan pada waktu menjalankan pembelajaran klinik.

Kata Kunci : Praktik Klinik, Mahasiswa Keperawatan.

\section{PENDAHULUAN}

Dalam ilmu keperawatan khususnya pendidikan DIII Keperawatan, praktik klinik menjadi bagian penting untuk mengembangkan kompetensi mahasiswa keperawatan. Praktik klinik dikatakan sebagai kunci dalam pembentukan mahasiswa keperawatan karena mahasiswa dapat menerapkan teori pengetahuan dan keterampilan yang diperoleh kepada pasien secara langsung. Dalam memberikan perawatan kepada pasien, mahasiswa praktik klinik seringkali menghadapi situasi sulit, hal ini tentunya sering menimbulkan stres karena adanya kontak langsung dengan penyakit, rasa sakit, penderitaan, kecacatan dan kematian pasien.

Stres dapat diartikan merupakan respon tubuh yang sifatnya non spesifik terhadap setiap tuntutan beban atasnya. Stres juga mengacu pada peristiwa yang dirasakan individu yang dapat membahayakan kesejahteraan fisik dan psikologis seseorang. Situasi-situasi tersebut dapat menyebabkan stres, akan tetapi reaksi individu terhadap stres akan berbeda-beda.

Salah satu yang mengalami stres adalah mahasiswa yang sedang melakukan praktik klinik di Rumah Sakit. Kompetensi yang diharapkan pada tiap tingkatan akan berbeda. Mahasiswa tingkat II dengan kompetesi dasar, sedangkan mahasiswa tingkat III dengan kompetensi gawat darurat, medikal bedah, maternitas dan anak. Hal ini tentunya akan memiliki tingkatan stres yang berbeda pula. Hal ini dikarenakan pada tahun pertama praktik akan menjadi masa transisi yaitu masa pendidikan dikelas (pengamat pasif) menjadi pendidikan di klinik (peserta aktif) Penelitian yang dilakukan Brien (2012) yang menyatakan bahwa beberapa penyebab stres antara lain 
kurangnya pengetahuan dan keterampilan klinik, kekhawatiran merawat pasien dan takut membuat kesalahan sehingga stres tersebut diwujudkan melalui kecemasan dan kesulitan dalam membuat keputusan

Hasil penelitian yang dilakukan oleh Chan (2006) yang membandingkan tingkat stres mahasiswa keperawatan dalam menjalani praktik klinik, hasilnya menunjukan bahwa tingkat stres bervariasi tergantung pada tingkatan semester, dan penempatan klinik. Sedangkan menurut Hehammer et al, (1990 dalam Chan, 2006) ditemukan bahwa mahasiswa tingkat II menunjukkan skor stres yang lebih tinggi dibandingkan dengan mahasiswa tingkat III.

\section{METODE PENELITIAN}

Penelitian ini menggunakan desain penelitian deskriptif kuantitatif dengan rancangan analisis deskiptif menggunakan pendekatan causal comparative. Waktu penelitian ini adalah tanggal 29 - 31 Januari 2019. Populasi dalam penelitian ini adalah mahasiswa tingkat II dan tingkat III Program Studi Diploma III Keperawatan yang sedang melakukan Studi Klinik yang masing-masing tingkat berjumlah 30 responden sehingga total responden adalah 60 responden.

Alat pengumpulan data yang digunakan adalah kuesioner yaitu Perceived Stress Scale (PSS) yang diadopsi dari Sheu et al (1997) untuk menilai tingkat stres dan
Stres praktik pada mahasiswa merupakan suatu reaksi adaptif yang bersifat sangat individual, sehingga stres pada seseorang belum tentu sama tanggapannya bagi orang lain. Hal ini sangat dipengaruhi oleh kematangan berfikir, tingkat pendidikan dan kemampuan adaptasi seseorang terhadap lingkungan (Sunarto \& Hartono, 2008). Berdasarkan hal tersebut maka peneliti tertarik untuk mengetahui perbedaan tingkat stres pada mahasiswa tingkat II dan tngkat III Program Studi Diploma III STIKes Kepanjen yang sedang melakukan studi klinik di rumah sakit.

sumber stres praktik klinik yang berisikan 29 item pernyataan. Respon memiliki 4 rentangan yaitu "tidak pernah" sampai ke "selalu", dan skoring dari $1-4$. Skala item ini dikelompokkan dalam 6 domain yang berhubungan dengan sumber stres antara lain stres merawat pasien (8 item), stres dari pengajar dan staf perawat (6 item), stres dari tugas dan beban kerja (5 item), stres dari teman sebaya dan kehidupan sehari-hari (4 item), stres kurangnya pengetahuan dan skill (3 item) dan stres dengan lingkungan rumah sakit (3 item). Data yang diperoleh akan dianalisa menggunakan Mann-Whitney.

\section{HASIL PENELITIAN}

Karakteristik responden dalam penelitian ini terdiri atas usia, jenis kelamin, dan pendidikan sebelumnya.

Tabel 1. Distribusi Frekuensi Berdasarkan Usia

\begin{tabular}{ccccccc}
\hline Usia & \multicolumn{2}{c}{ Tingkat III } & \multicolumn{2}{c}{ Tingkat II } & \multicolumn{2}{c}{ Total } \\
\cline { 2 - 7 } & $\begin{array}{c}\text { Jumlah } \\
\text { Responde } \\
\mathbf{n}(\mathbf{N})\end{array}$ & $\begin{array}{c}\text { Prosentas } \\
\mathbf{e} \\
(\%)\end{array}$ & $\begin{array}{c}\text { Jumlah } \\
\text { Responde } \\
\mathbf{n}(\mathbf{N})\end{array}$ & $\begin{array}{c}\text { Prosentas } \\
\mathbf{e} \\
(\%)\end{array}$ & $\begin{array}{c}\text { Jumlah } \\
\text { Responde } \\
\mathbf{n}(\mathbf{N})\end{array}$ & $\begin{array}{c}\text { Prosentas } \\
\mathbf{e} \\
(\%)\end{array}$ \\
\hline$<19$ & 1 & 3,33 & 5 & 16,67 & 6 & 10 \\
20 & 11 & 36,67 & 22 & 73,33 & 33 & 55 \\
21 & 11 & 36,67 & 2 & 6,67 & 13 & 21,7 \\
22 & 3 & 10 & 0 & 0 & 3 & 5 \\
23 & 0 & 0 & 1 & 3,33 & 1 & 1,7 \\
$>23$ & 4 & 13,33 & 0 & 0 & 4 & 6,6 \\
\hline Jumlah & 30 & 100 & 30 & 100 & 60 & 100 \\
\hline
\end{tabular}


Tabel 2. Distribusi Frekuensi Berdasarkan Jenis Kelamin Responden

\begin{tabular}{ccccccc}
\hline $\begin{array}{c}\text { Jenis } \\
\text { Kelamin }\end{array}$ & $\begin{array}{c}\text { Jumlah } \\
\text { Responden } \\
(\mathbf{N})\end{array}$ & $\begin{array}{c}\text { Prosentase } \\
(\%)\end{array}$ & $\begin{array}{c}\text { Jumlah } \\
\text { Responden } \\
(\mathbf{N})\end{array}$ & $\begin{array}{c}\text { Prosentase } \\
(\%)\end{array}$ & $\begin{array}{c}\text { Jumlah } \\
\text { Responden } \\
(\mathbf{N})\end{array}$ & $\begin{array}{c}\text { Prosentase } \\
(\%)\end{array}$ \\
\hline Laki-laki & 12 & 40 & 3 & 10 & 15 & 25 \\
Perempuan & 18 & 60 & 27 & 90 & 45 & 75 \\
\hline Jumlah & 30 & 100 & 30 & 100 & 60 & 100
\end{tabular}

Berdasarkan Tabel 1, diketahui bahwa lebih dari setengah usia responden berusia 20 tahun (55\%). Sedangkan pada Tabel 2, diketahui bahwa sebagian besar responden adalah berjenis kelamin perempuan $(75 \%)$.

Tabel 3. Distribusi Frekuensi Berdasarkan Pendidikan Sebelumya

\begin{tabular}{ccccccc}
\hline Pendidikan & \multicolumn{2}{c}{ Tingkat III } & \multicolumn{2}{c}{ Tingkat II } & \multicolumn{2}{c}{ Total } \\
& $\begin{array}{c}\text { Jumlah } \\
\text { Responden } \\
(\mathbf{N})\end{array}$ & $\begin{array}{c}\text { Prosentase } \\
(\%)\end{array}$ & $\begin{array}{c}\text { Jumlah } \\
\text { Responden } \\
(\mathbf{N})\end{array}$ & $\begin{array}{c}\text { Prosentase } \\
(\%)\end{array}$ & $\begin{array}{c}\text { Jumlah } \\
\text { Responden } \\
(\mathbf{N})\end{array}$ & $\begin{array}{c}\text { Prosentase } \\
(\%)\end{array}$ \\
\hline $\begin{array}{c}\text { SMA } \\
\text { SMK Non }\end{array}$ & 21 & 70 & 20 & 66,7 & 41 & 68,3 \\
$\begin{array}{c}\text { Keperawatan } \\
\text { SMK }\end{array}$ & 6 & 20 & 2 & 6,7 & 8 & 13,3 \\
Keperawatan & 3 & 10 & 8 & 26,6 & 11 & 18,3 \\
\hline Jumlah & 30 & 100 & 30 & 100 & 60 & 100 \\
\hline
\end{tabular}

Pada tabel 3, menunjukkan bahwa responden lebih dari setengah berpendidikan SMA yaitu sebanyak 41 responden (68,33\%). Sedangkan untuk tingkat stres mahasiswa praktik klinik dapat dilihat pada tabel berikut:

Tabel 4. Tingkat Stres Mahasiswa Praktik Klinik

\begin{tabular}{ccccccc}
\hline $\begin{array}{c}\text { Tingkat } \\
\text { Stres }\end{array}$ & $\begin{array}{c}\text { Jumlah } \\
\text { Responden } \\
(\mathbf{N})\end{array}$ & $\begin{array}{c}\text { Prosentase } \\
(\%)\end{array}$ & $\begin{array}{c}\text { Jumlah } \\
\text { Responden } \\
(\mathbf{N})\end{array}$ & $\begin{array}{c}\text { Prosentase } \\
(\%)\end{array}$ & $\begin{array}{c}\text { Tumlah } \\
\text { Responden } \\
(\mathbf{N})\end{array}$ & $\begin{array}{c}\text { Prosentase } \\
(\%)\end{array}$ \\
\hline Ringan & 1 & 3,3 & 5 & 16,7 & 6 & 10 \\
Sedang & 27 & 90 & 25 & 83,3 & 52 & 86,7 \\
Berat & 2 & 6,7 & 0 & 0 & 2 & 3,3 \\
\hline Total & 30 & 100 & 30 & 100 & 60 & 100 \\
\hline
\end{tabular}

Berdasarkan tabel diatas, diperoleh hasil bahwa lebih dari setengah responden mengalami tingkat stres sedang yaitu $86,7 \%$. Untuk sumber stres yang sering dirasakan oleh responden dilihat pada tabel berikut ini:

Tabel 5. Hasil Analisis Mann-Whitney Test Perbedaan Tingkat Stres Mahasiswa Studi Klinik

\begin{tabular}{cc} 
Tabel 5. Hasil Analisis Mann-Whitney Test Perbedaan Tingkat Stres Mahasiswa Studi Klinik \\
\hline & Tingkat stres \\
\hline Mann-Whitney U & 365.000 \\
Wilcoxon W & 830.000 \\
Z & -2.130 \\
\hline Asymp. Sig (2-tailed) & .033
\end{tabular}

Dengan uji Mann-Whitney, diperoleh angka significancy 0,033 . Karena nilai $p<0,05$, dapat disimpulkan bahwa terdapat perbedaan bermakna antara stres mahasiswa studi klinik pada tingkat II dan tingkat III. 
Tabel 6. Sumber Stres

\begin{tabular}{|c|c|c|c|c|c|c|}
\hline \multirow{2}{*}{ Sumber stres } & \multicolumn{3}{|c|}{ Tingkat II } & \multicolumn{3}{|c|}{ Tingkat III } \\
\hline & $\mathbf{R}$ & S & $\mathbf{T}$ & $\mathbf{R}$ & $\mathrm{s}$ & $\mathbf{T}$ \\
\hline Stres merawat pasien & 15 & 15 & - & 16 & 13 & 1 \\
\hline $\begin{array}{l}\text { Stres dari pengajar dan staf } \\
\text { keperawatan }\end{array}$ & 21 & 9 & - & 10 & 17 & 3 \\
\hline Stres dari tugas dan beban kerja & 17 & 13 & - & 9 & 18 & 3 \\
\hline $\begin{array}{l}\text { Stres dari teman sebaya dan } \\
\text { kehidupan sehari-hari }\end{array}$ & 23 & 7 & - & 14 & 15 & 1 \\
\hline $\begin{array}{l}\text { Stres karena kurang } \\
\text { pengetahuan dan skill }\end{array}$ & 10 & 20 & - & 6 & 23 & 1 \\
\hline $\begin{array}{l}\text { Stres karena lingkungan rumah } \\
\text { sakit }\end{array}$ & 17 & 13 & - & 10 & 18 & 2 \\
\hline
\end{tabular}

Ket : Rendah (R), Sedang (S), Tinggi (T).

Dari hasil tabel diatas, sumber stres tertinggi yang dirasakan oleh responden baik tingkat II maupun tingkat III, adalah kurangnya pengetahuan atau skillyang masing-masing berjumlah 20 responden $(66,67 \%)$, dan 23 responden $(76,7 \%)$. Sumber stres peringkat kedua adalah tugas dan beban kerja serta lingkungan rumah sakit yang masing-masing sebanyak 18 responden (60\%) pada tingkat II dan 13 responden $(43,33 \%)$ pada tingkat II. Sedangkan sumber stres peringkat ke-tiga adalah merawat pasien sebanyak 13 responden (43,33\%) pada tingkat III dan 15 responden $(50 \%)$ pada tingkat II.

\section{PEMBAHASAN}

Berdasarkan pada hasil penelitian yang telah dijelaskan diatas, responden memiliki karakteristik usia yang lebih dari setengah oleh usia 20 tahun sebanyak 33 responden (55\%) dimana usia tersebut termasuk dalam kategori remaja akhir. Dimana remaja akhir memiliki karakteristik antara lain mulai mandiri secara emosional, mempersiapkan karir, mengembangkan keterampilan intelektual dan memiliki perilaku bertanggungjawab secara sosial (Havighrust, 1983). Sedangkan untuk karakteristik jenis kelamin,lebih dari setengah oleh perempuan sebanyak 45 responden $(75 \%)$. Hal ini, dikarenakan perempuan dianggap sosok yang memiliki jiwa lembut, ketelatenan dalam memberikan perawatan, khususnya kepada pasien. Namun jika dilihat dari distribusi responden lebih dari setengaholeh pendidikan SMA yaitu sebanyak 41 responden $(68,33 \%)$.

Hasil analisis Mann-Whitney bahwa terdapat perbedaan secara signifikan tingkat stres pada mahasiswa yang sedang melakukan praktik klinik antara tingkat II dan tingkat III. Meskipun mayoritas mahasiswa tingkat II dan tingkat III berada pada tingkat stres sedang. Namun, hal ini tentunya memiliki makna yang berbeda. Tingkat Stres pada tingkat II dikarenakan praktik klinik merupakan pengalaman pertama sehingga mengalami kecemasan tersendiri. Berbeda dengan mahasiswa tingkat III, menjadikan stres tersendiri karena adanya kompetensi yang harus dicapai lebih banyak yaitu medikal bedah, gawat darurat, maternitas dan anak dalam jangka praktik yang lebih lama, ditambah lagi adanya beban untuk menyelesaikan tugas akhir. Hal ini sependapat dengan penelitian yang telah dilakukan oleh Chiang (2012) bahwa mahasiswa tingkat III dalam melakukan praktik klinik memiliki tingkat stres lebih tinggi dibandingkan mahasiswa tingkat II.

Jika ditinjau dari faktor penyebab stres, dalam penelitian ini terdapat 3 penyebab yang paling mendominasi. Penyebab stres yang pertama adalah kurangnya pengetahuan dan keterampilan sebesar 43 responden. Hal ini sependapat dengan penelitian yang telah dilakukan oleh Finn, Thorburn dan King (2000) yang dikutip dari Syahreni dan Waluyanti (2007) bahwa banyak mahasiswa yang mengalami kesulitan saat berhadapan dengan masalah-masalah nyata selama menjalani pembelajaran klinik. Penyebabnya bervariasi, diantaranya adalah keterbatasan pemahaman tentang tugas, lingkungan baru dan pengalaman berinteraksi dengan pasien. Untuk itu keberhasilan mahasiswa dalam melakukan praktik klinik sangat dipengaruhi oleh kesiapan pengetahuan, mental, emosi dan ketersediaan lingkungan pembelajaran yang kondusif.

Sumber stres peringkat ke-dua adalah banyaknya tugas dan beban kerja serta lingkungan klinik. Hal ini juga sependapat dengan hasil penelitian yang dilakukan oleh Nolan \& Ryan (2008) yang menyatakan bahwa mahasiswa yang menjalani praktik klinik dangan waktu kerja yang padat dianggap sebagai sumber stres, karena merasa lelah pada hari-hari libur mereka dan kesulitan 
dalam menemukan waktu untuk menyelesaikan tugas - tugas mereka (Shipton, 2002). Kekhawatiran mahasiswa mendapatkan nilai buruk, serta dalam memenuhi tuntutan praktik klinik yang melebihi daya tahan fisik dan emosi (Khater, 2014). Tekanan yang lain berasal dari lingkungan praktik adalah adanya pembimbingan yang membandingkan mahasiswa satu dengan yang lain, sehingga

\section{KESIMPULAN DAN SARAN}

Dari penelitian yang telah dilakukan, dapat disimpulkan bahwa terdapat perbedaan secara signifikan tingkat stres mahasiswa praktik klinik pada tingkat II dan tingkat III Program Studi Diploma III Keperawatan STIKes Kepanjen. Sedangkan untuk faktor penyebab stres yang dirasakan oleh pada mahasiswa yang melakukan studi klinik adalah kurangnya pengetahuan, dan pengalaman,

\section{DAFTAR PUSTAKA}

Brien, L., Kathleen, M., Joan, L., Lori, R.S. (2012). Level Of Stress and Common Copping Strategies Among Physician Assistant Student. The Journal of Physician Assist Edr. Vol. 43. No. 4, 2529.

Chan, C.K.L, So, W.K.W \& Fong, D.Y.T. (2009). Hong Kong Baccalaureate Nursing Student' Stress and Their Coping Strategies in Clinical Practice. Journal of Professional Nursing, 25 (5), 307-313.

Chiang, Y.M, Chang, Y. (2012). Stress, Depression and Intention to Leave Among Nurse in Different Medical Unit : Implication for Healthcare Management Nursing Practice. Health Policy, 108 : 149 - 157

Khater, Wejdan. A. (2012). Sources of Stress and Coping Behaviours in Clinical Practice among Baccalaureate Nursing Students. Internasioanal Journal of berdampak pada kemampuan bergaul pada saat praktik klinik dan juga berdampak pada kegiatan diluar praktik klinik.

Sumber stres yang menjadi peringkat ketiga adalah stres merawat pasien, hal ini dikarenakan mahasiswa merasa kurang memiliki pengalaman, serta kurangnya kemampuan dalam menyediakan perawatan dan membuat keputusan pada suatu tindakan.

banyak nya tugas dan lingkungan praktik serta staf pengajar. Untuk itu, disarankan pada praktik selanjutnya pihak program studi lebih mempersiapkan mahasiswa lebih optimal dalam segi kematangan dalam menghadapi permasalahan, pengetahuan yang mumpuni dan keterampilan yang memadai agar tujuan dari praktik klinik dapat tercapai dengan maksimal.

Humanities and Social Science Vol. 4, No. 6 April 2014. Jordan University of Science and Technology Jordan.

Nilan, G., \& Ryan, D. (2008). Experience of Stress in Psychiatric Nursing Student in Ireland. Nursing Standart, 22 (43), 35-43.

Shipton, S.P. (2002). The Process of Seeking Stress Care: Coping as Experienced by Senior Baccalaureate Nursing Student in Response to Appraised Clinical Stress. Journal of Nursing Education, 41(6), 243256.

Sunarto \& Hartono, 2008. Perkembangan Peserta Didik. Jakarta : Rineka Cipta

Sunaryo. 2004. Psikologi Untuk Keperawatan. Jakarta : EGC.

Syahreni, E \& Waluyanti, F.T (2007). Pengalaman Mahasiswa S1 Keperawatan Program Reguler dalam Pembelajaran Klinik. Jurnal Keperawatan Indonesia 11(2), 47-53. 